\title{
REGULASI PENDIDIKAN ISLAM
}

\author{
Zulkifli \\ Zulkifli.royani123@mail.com \\ (Dosen Fakultas Agama Islam, Universitas Muhammadiyah Tangerang )
}

\begin{abstract}
Abstrak:
Pendidikan merupakan salah satu tujuan negara Indonesia yang diselenggarakan untuk meningkatkan keimanan dan akhlak mulia. Keimanan tersebut hanya dapat diusahakan secara optimal melalui pendidikan keagamaan, baik melalui muatan materinya maupun lembaganya. Pemerintah mengeluarkan regulasi terkait pendidikan Islam seperti Undangundang No. 20 tentang Sistem Pendidikan Nasional, Undang-Undang Nomor 12 tahun 2012 tentang Pendidikan Tinggi, dan Peraturan Pemerintah Nomor 55 tahun 2007 tentang Pendidikan Agama dan Pendidikan Keagamaan. Keberadan pendidikan Islam diakui dalam tata hukum Indonesia melalui materi kurikulum pendidikan agama Islam yang diwajibkan dalam setiap jenjang pendidikan.
\end{abstract}

Kata Kunci: Regulasi, Pendidikan, Islam.

\section{A. Pendahuluan}

Indonesia telah mengalami berbagai kondisi pemerintahan, dari pemerintahan orde lama, orde baru, dan reformasi. Setelah memasuki masa reformasi ini, pemerintah hampir merubah seluruh ketentuan peraturan perundang-undangan yang terkait dengan pelaksanaan pemerintahan termasuk ketentuan mengenai pendidikan nasional dan pendidikan Islam. Undang-Undang Dasar 1945 sebagai norma dasar menyatakan bahwa tujuan negara Indonesia mengamanatkan agar pemerintah negara Indonesia melindungi segenap bangsa Indonesia dan seluruh tumpah darah Indonesia dan untuk memajukan kesejahteraan umum, mencerdaskan kehidupan bangsa, dan ikut melaksanakan ketertiban dunia yang berdasarkan kemerdekaan, perdamaian abadi dan keadilan sosial. ${ }^{1}$

Tujuan umum pendidikan islam dengan tujuan pendidikan nasional di

${ }^{1}$ Tim Pengembang Ilmu Pendidikan FIP UPI. Ilmu dan Aplikasi Pendidikan. Jakarta: Imtima, 2007. Hlm. 35. indonesia pada hakikatnya tidak bertentangan bahkan mempunyai titik persamaan, apabila pendidikan nasional diletakkan secara profesional dalam rangka pendidikan nasional, maka pendidikan islam dapat menciptakan insan yang beriman dan bertaqwa seperti yang dirumuskan di dalam program pemerintah, dan sekaligus berarti mendidik insan pancasila dan insan yang beragama. ${ }^{2}$

Pendidikan merupakan salah satu tujuan negara Indonesia yang diselenggarakan untuk meningkatkan keimanan dan akhlak mulia. Keimanan tersebut hanya dapat diusahakan secara optimal melalui pendidikan keagamaan, baik melalui muatan materinya maupun lembaganya.

\section{B. Pengertian Pendidikan Islam}

Pendidikan Islam merupakan suatu upaya yang terstruktur dengan melibatkan lembaga pendidikan Islam dan materi pendidikan Islam membangun tatanan akhlak mulia sehingga cita-cita masyarakat

${ }^{2}$ Ramayulis. Ilmu Pendidikan Islam. Jakarta: klam mulia, 1994. Hlm: 32 
Islami dapat terwujud dan berkarakter sesuai dengan konsekuensinya sebagai seorang muslim. Ahmad D. Marimba menyatakan pendidikan Islam adalah bimbingan jasmani dan rohani berdasarkan hukum-hukum agama Islam menuju kepada terbentuknya kepribadian utama menurut ukuran Islam atau memiliki kepribadian muslim. ${ }^{3}$

Selanjutnya menurut Hasan Langgulung Pendidikan Islam adalah sebagai suatu proses penyiapan generasi muda untuk mengisi peranan, memindahkan pengetahuan, dan nilai-nilai Islam yang diselaraskan dengan fungsi manusia untuk beramal di dunia dan memetik hasilnya diakhirat. ${ }^{4}$ Pendidikan Islam adalah pendidikan manusia seutuhnya, akal, dan hatinya, rohani dan jasmaninya, akhlak, dan keterampilannya. ${ }^{5}$ Karena itu pendidikan Islam menyiapkan manusia untuk hidup baik dalam keadaan damai maupun perang, dan menyiapkannya untuk menghadapi masyarakat dengan segala kebaikan dan kesejahtraannya, manis dan pahitnya. Pendidikan Islam secara konseptual adalah pendidikan yang memenuhi persyaratan yang dibutuhkan oleh masyarakat maju dengan memiliki sifat demokratis, robbaniyah, seimbang, terbuka dan fleksibel. ${ }^{6}$

Berdasarkan penjelasan tersebut, maka dapat dipahami ilmu pendidikan Islam, adalah:

a. Ilmu pengetahuan ilmiah dan praktis, karena memindahkan pengetahuan dan

${ }^{3}$ Moh Roqib. Ilmu Pendidikan Islam. Yogyakarta: LkiS Pelangi Aksara, 2009. Hlm. 20

${ }^{4}$ Hasan Langgulung.Beberapa Pemikiran Tentang Pendidikan Islam. Bandung: Al-Ma'rif, 1980. Hlm. 94

${ }^{5}$ Azyumardi Azra.pendidikan islam tradisi dan modernisasi menuju millennium baru. Jakarta: logos wacana ilmu, 1999. Hlm. 5.

${ }^{6}$ Abuddin Nata. Pendidikan dalam Perspektif Alquran Edisi Pertama. Jakarta: Kharisma Putra Utama, 2016. Hlm. 33-37. nilai-nilai Islam yang digunakan oleh manusia dalam beramal di dunia.

b. Ilmu pengetahuan normatif, karena ilmu ini berdasarkan pada ajaran Islam, yakni al-Qur'an dan al-Sunnah.

c. Ilmu pengetahuan yang terpadu,karena dilaksanakan melalui bimbingan jasmani dan rohani untuk mengarahkan akal, akhlak, dan hatinya sehingga manusia dapat beradaptasi kapanpun dan dimanapun. Sebagaiman dinyatakan oleh Mahmud Syaltout bahwa al-Islam shalihun li kulli zaman wa makan.

Pendidikan Islam menjadikan pedomannya pada Al-qur'an dan Hadis yang berwujud aplikasi pada akhlak manusia. Manusia yang melaksanakan pendidikan, maka dia taat pada Allah dan melaksanakan ibadah kepada-Nya (QS. An-Nahl [16]: 125).

Dalam Al-qur'an ajaran-ajarannya bersifat universal dan tentu saja harus selalu digali atau dipahami secara mendalam dengan kecerdasan manusia supaya dapat menemukan makna yang dalam dan luas. Eksistensi al-qur'an sebagai sumber ajaran pokok utama pendidikan Islam. Akan tetapi karena terdapat beberapa ayat bersifat global, yang memerlukan penjelasan lebih rinci, dimana penjelasan tersebut terdapat dalam hadis. Karena itulah dalam dasar pendidikan Islam, hadis menjadi sumber ajaran pokok kedua setelah al-qur'an. Keberadaan Sunnah adalah sebagai penjelasan keuniversalan ajaran al-qur'an bersamaan dengan itu sebagai petunjuk bagi kemaslahatan hidup manusia sepanjang zaman. ${ }^{7}$

Sebagai satu sistem pendidikan yang terdapat dalam kerangka negara Indonesia, maka pendidikan Islam kaitannya dengan Indonesia dapat di lihat dari dua perspektif,

${ }^{7}$ Asep Herdi dan Asep Supriatna. Memahami Ilmu Hadis. Bandung: Tafakur, 2014. Hlm. 1 
yaitu: pendidikan Islam sebagai lembaga pendidikan dan pendidikan Islam sebagai mata pelajaran. Sebagai lembaga pendidikan Islam di Indonesia, pendidikan Islam sudah mampu membentuk lembaga pendidikan, baik secara formal, in-formal maupun non-formal. Sedangkan pendidikan Islam sebagai materi pembelajaran pendidikan Islam hampir secara umum sudah masuk dalam kurikulum nasional yang diberikan kepada seluruh sekolah baik sekolah umum maupun sekolah keagamaan. Ini berarti dalam konteks dasar pendidikan, pendidikan Islam memberikan kontribusi positif dalam perkembangan pedidikan nasional.

\section{Pendidikan Islam dalam Pendidikan Nasional}

Pada masa pemerintahan Hindia Belanda, keberadaan lembaga pendidikan Islam terpinggirkan tidak seperti sekolahsekolah Missie dan Zending yang dibantu oleh pemerintah Belanda. ${ }^{8}$ Selain itu terdapt sekolah-sekolah Belanda lainnya seperti: Europeesche Lagere School (ELS) dan Holland Inlandsche School (HIS) untuk tingkat sekolah dasar, Meer Unitgebreid Lager Onderwijs (MULO)untuk tingkat lanjutan pertama, Algeemene Middelbare School (AMS) tingkat menengah. ${ }^{9}$

Walaupun begitu, lembaga-lembaga pendidikan Islam tetap berkembang atas dasar dukungan dan kekuatan masyarakat

\footnotetext{
${ }^{8}$ Aqib Suminto dalam Politik Islam, sebagaiman dikutip oleh Imam Fuadi. Sejarah Pendidikan Islam. Tulungagung: IAIN Tulungagung Press, 2014 hlm. 178. Sekolah Missie dan Zending dikelolah oleh masyarakat kristen. Sejarah nasional Indonesia: Jaman kebangkitan nasional dan masa akhir Hindia Belanda. Departemen Pendidikan dan Kebudayaan, 1975 hlm. 62.

${ }^{9}$ Atas Hendartini Habsjah dan Mooriati Sudiharto. Perjalanan Panjang Anak Bumi. Jakarta: Yayasan Obor Indonesia, 2008. Hlm. 32.
}

sendiri. Dengan demikian, sejak saat itu sudah ada kerangka dikotomi dalam sistem pendidikan untuk rakyat Indonesia yaitu antara pendidikan pemerintahan Hindia Belanda dan pendidikan Islam. Berbeda dengan masa setelah kemerdekaan, saat ini sekolah islam sudah banyak mendapat pengakuan, bahkan mendapat subsidi dana dari pemerintah, karena menggunakan sistem dan kurikulum yang hampir sama dengan sekolah-sekolah pemerintah atau sistem pelaksanaan sekolah sesuai dengan ketentuan yang diatur pemerintah. Sementara itu, pesantren yang masih belum menyesuaikan dengan ketentuan pemerintah, maka tidak mendapat fasilitas tersebut karena terdapat jarak (non kooperatif) dengan sistem pendidikan nasional, baik karena alasan agamis maupun politik.

Pada masa-masa awal kemerdekaan, Indonesia mengembangkan pendidikan sekolah sebagai bentuk pelaksanaan amanat UUD 1945 melalui sistem pendidikan nasional. Akan tetapi pengelolaan dan pengawasan pendidikan masih meniru apa yang diwariskan oleh pemerintah Hindia Belanda. Dengan demikian, dikotomi antara sistem pendidikan nasional dengan sistem pendidikan islam pun terus berlangsung. Hal tersebut dapat dilihat dalam kebijakan pemerintah terkait pendidikan yang diatur dalam Undang-Undang Nomor 4 tahun 1950 jo Undang-Undang Nomor 12 tahun 1954 tentang Dasar-Dasar Pendidikan dan Pengajaran di Sekolah dan Undang-undang No. 2 tahun 1989 tentang Sistem Pendidikan Nasional. Dalam ketentuan tersebut sebagaimana diatur dalam penjelasan pasal 13 , pasal 14 dan pasal 15 mengenai pendidikan dasar dan pendidikan menengah yang dengan tidak menyatakan Madrasah Ibtidaiyah (MI), Madrasah Tsanawiyah (MTs), dan Madrasah Aliyah (MA) dalam jalur pendidikan sekolah. Walaupun demikian, pendidikan agama 
wajib diberikan pada setiap jenis, jalur, dan jenjang pendidikan sebagaimana diatur dalam pasal 39.

Tahun 2003 diundangkan Undangundang No. 20 tahun 2003 tentang Sistem Pendidikan Nasional. Hal mendasar yang dirubah dalam ketentuan tersebut adalah pengaturan mengenai jenjang pendidikan. Dalam pendidikan dasar dan pendidikan menengah diakui keberadaan Madrasah Ibtidaiyah (MI), Madrasah Tsanawiyah (MTs), dan Madrasah Aliyah (MA) sebagai jenjang pendidikan formal. Sehingga peserta didik yang lulus dari sekolah tersebut dipersamakan dengan jenjang sekolah yang lain untuk mendapatkan haknya dalam memperoleh pendidikan yang bermutu. Hal tersebut diatur dalam ketentuan Pendidikan Dasar pasal 17 ayat (2) bahwa pendidikan dasar berbentuk Sekolah Dasar (SD) dan Madrasah Ibtidaiyah (MI) atau bentuk lain yang sederajat serta Sekolah Menengah Pertama (SMP) dan Madrasah Tsanawiyah (MTs), atau bentuk lain yang sederajat. Serta Pendidikan Menengah yang diatur dalam pasal 18 ayat (3) pendidikan menengah berbentuk Sekolah Menengah Atas (SMA), Madrasah Aliyah (MA), Sekolah Menengah Kejuruan (SMK), dan Madrasah Aliyah Kejuruan (MAK), atau bentuk lain yang sederajat.

Salah satu point penyesuaian itu, terletak pada cakupan sistem pendidikan yang komprehensif. Apa yang disebut dengan sistem pendidikan nasional adalah salah satu kesatuan dari jalur dan satuan pendidikan yang beraneka ragam, dengan dasar dan tujuan pendidikan yang bersifat nasional. Meskipun hanya terdapat satu sistem pendidikan nasional di indonesia, tetapi diakui adanya jalur, satuan, dan pengelolaan pendidikan yang berbedabeda. Sehingga, termasuk ke dalam bagian dari sistem pendidikan nasional yaitu lembaga pendidikan keagamaan.
Undang-Undang nomor 20 tahun 2003 tentang Sistem Pendidikan Nasional, mengistilahkan penyeragaman terhadap kriteria minimal sebagai standar nasional pendidikan. Tujuannya untuk menghasilkan pendidikan yang bermutu dan berdaya saing dalam menghadapi tantangan nasional dan global. Standar nasional pendidikan dapat digunakan untuk mempertemukan tradisi pendidikan yang berkembang di masyarakat dengan kebijakan negara yang bisa disepakati. Dengan demikian Standar nasional pendidikan diperlukan agar negara dapat melestarikan keragaman dengan memberikan jaminan kepada lembaga pendidikan lainnya termasuk lembaga pendidikan keagamaan agar saling bersinergi dan saling melengkapi dalam peningkatan pendidikan. ${ }^{10}$

Penyesuaian dalam sistem pendidikan nasional dilakukan terhadap kurikulum yang menempatkan agama sebagai salah satu muatan wajib dalam semua jalur dan satuan pendidikan. Hal ini memberi jaminan adanya itikad baik mengenai keagamaan agar dapat diberikan kepada seluruh sekolah yaitu sekolah umum dan sekolah swasta. Selain itu, diberikan kesempatan yang sama terhadap lulusan kedua sekolah tersebut untuk melanjutkan pendidikan kejenjang lanjutan tanpa diskriminasi. Lulusan sekolah umum dapat melanjutkan ke sekolah jenjang lanjutan yang bercirikan khas keagamaan ataupun sebaliknya.

Pendidikan Islam merupakan nyawa dalam proses pendidikan yang dilaksanakan. Hal ini terbukti pula bahwa pendidikan agama yang merupakan mata pelajaran wajib yang diajarkan di sekolahsekolah, di samping posisi yang tepat dan

\footnotetext{
${ }^{10}$ Depertemen Agama Direktorat Jendral. Kelembagaan Agama Islam. Pendidikan Islam dan Pendidikan Nasional (Paradigma Baru). Jakarta: 2005. Hlm.12.
} 
strategis tersebut, pendidikan Islam telah memperlihatkan eksistensinya dalam membantu keberhasilan pendidikan nasional, yakni untuk mencerdaskan bangsa dan menanamkan nilai ketaqwaan kepada Tuhan Yang Maha Esa Kedudukan pendidikan Islam yang merupakan sub sistem dari pendidikan nasional, mengharuskan seluruh kebijakan pendidikan yang berada dalam otoritas Departemen Agama, menyerap berbagai aturan yang merupakan implementasi dari kebijakan pendidikan secara nasional. ${ }^{11}$

Kedudukan Pendidikan Islam dalam Sistem Pendidikan Nasional yang dinyatakan dalam Bab VI Jalur, Jenjang dan Jenis Pendidikan pada Bagian ke Sembilan Pendidikan Keagamaan Pasal 30 diatur sebagai berikut:

a. Pendidikan keagamaan diselenggarakan oleh pemerintah dan/atau kelompok masyarakat dari pemeluk agama, sesuai dengan peraturan perundang-undangan.

b. Pendidkan keagamaan berfungsi mempersiapkan peserta didik menjadi anggota masyarakat yang memahami dan mengamalkan nilai-nilai ajaran agamnya dan/atau menjadi ahli ilmu agama.

c. Pendidkan keagamaan dapat diselenggarakan pada jalur pendidikan formal, informal dan nonformal.

d. Pendidikan keagamaan berbentuk pendidikan diniyah, pesantren, pasraman, pabhaja samanera dan bentuk lain yang sejenis.

e. Ketentuan mengenai pendidikan keagmaan sebagaimana dimaksud dalam ayat 1,2,3 dan 4 diatur lebih lanjut dengan Peraturan pemerintah.

Dengan ketentuan tersebut menjadikan kedudukan pendidikan Islam mendapat posisi yang lebih baik, sehingga

\footnotetext{
${ }^{11}$ Syafaruddin. Pendidikan dan Pemberdayaan Masyarakat. Medan: Perdana Publishing. Hlm. 103
}

keberadaannya memiliki peran sangat penting dan guru memiliki semangat untuk mengikuti praktek-praktek pendidikan dan keagamaan yang mengakibatkan siswa mendapat banyak manfaat saat belajar di sekolah. ${ }^{12}$

Ketentuan terkait pendidikan Islam dalam Sistem Pendidikan Nasional, telah mengalami penyesuaian dalam memenuhi kedudukan pendidikan Islam, baik sebagai mata pelajaran atau sebagai lembaga pendidikan yaitu:

a. Sebagai Mata Pelajaran. Istilah "Pendidikan Agama Islam" di Indonesia dipergunakan untuk nama suatu mata pelajaran yang didalamnya dipelajari secara ringkas berbagai hal terkait agama Islam. Pelajaran tersebut termasuk ke dalam kelompok mata pelajaran wajib dalam setiap jalur, jenis, dan jenjang pendidikan, beriringan dengan mata pelajaran lain. Kemudian, apabila anak yang sekolah di lembaga pendidikan keagamaan yang berbeda dengan keyakinannya, maka lembaga pendidikan tersebut wajib menyediakan guru agama sesuai dengan keyakinan agama peserta didik.

b. Sebagai Lembaga. Lembaga pendidikan yang berada dibawah Kementerian Agama diwujudkan sebagai satuan pendidikan yang berjenjang naik mulai dari Raudatul Athfal (RA)sampai dengan perguruan tinggi. Walaupun lembaga pendidikan Islam dalam kurikulum berbeda dengan lembaga pendidikan umum, tetapi keduanya diberikan hak yang sama untuk melanjutkan pendidikan ke jenjang lebih tinggi dalam kesempatan untuk masuk perguruan tinggi Islam negeri atau swasta serta berlaku juga

\footnotetext{
${ }^{12}$ Nanang Martono. Sekolah Publik VS Sekolah Privat: Dalam wacana kekuasaan, Demokrasi, dan Liberalisasi Pendidikan. Jakarta: Pustaka Obor. Hlm. 181.
} 
sebaliknya dalam masuk perguruan tinggi negeri atau swasta. Hal tersebut sesuai dengan Undang-Undang No. 20 Tahun 2003 tentang Sistem Pendidikan Nasional. Dimana dalam penjelasan Undang-Undang Sistem Pendidikan Nasional mengenai agama dijelaskan bahwa pendidikan agama dimaksudkan untuk membentuk peserta didik menjadi manusia yang beriman dan bertakwa kepada Tuhan Yang Maha Esa serta berakhlak mulia. Pendidikan Agama Islam memiliki karakteristik tersendiri yaitu bahwa materi yang diajarkan tidak cukup hanya diketahui saja, tetapi dituntut pula untuk diamalkan. Sehingga guru yang mengajarkan pelajaran tersebut adalah guru yang memiliki perilaku yang dapat diteladani, misalnya dalam pelaksanaan sholat wajib berjamaah ${ }^{13}$ Dengan demikian, jelas bahwa kedudukan pendidikan agama islam sebagai pelajaran yang diajarkan di sekolah umum adalah segala penyampaian ilmu pengetahuan agama islam, tidak hanya untuk dipahami dan dihayati saja melainkan harus diamalkan. Hal ini sesuai dengan UUD 1945 yang menjamin warga negara untuk beribadah menurut agamanya masing-masing. Pendidikan agama islam merupakan usaha sadar untuk menyiapkan peserta didik meyakini, memahami, menghayati, dan mengamalkan agama islam melalui kegiatan bimbingan, pengajaran, dan atau latihan untuk mewujudkan pribadi muslim yang beriman dan bertwakwa kepada Allah serta berakhlak mulia. Sementara itu, dalam kehidupan pribadi, bermasyarakat, berbangsa, dan

\footnotetext{
${ }^{13}$ Abdul Rachman Saleh. Pendidikan Agama dan Keagamaan, Visi, Misi, dan Aksi. Jakarta: PT Maries, 1999.
}

bernegara, serta memiliki bekal untuk kehidupan yang lebih tinggi. ${ }^{14}$

Dalam ketentuan sistem pendidikan nasional diatur mengenai pengertian pendidikan yang merupakan usaha sadar dan terencana untuk mewujudkan suasana belajar dan proses pembelajaran agar peserta didik secara aktif mengembangkan potensi dirinya untuk memiliki kekuatan spiritual keagamaan, pengendalian diri, kepribadian, kecerdasan, akhlak mulia, serta keterampilan yang diperlukan dirinya, masyarakat, bangsa dan negara. ${ }^{15}$ Oleh karena itu, pendidikan agama sebagai mata pelajaran yang wajib ada dalam setiap jenjang pendidikan dari mulai pendidikan dasar sampai dengan perguruan tinggi baik sekolah umum ataupun sekolah keagamaan Islam. Jika pendidikan agama yang diperoleh dari sekolah dirasakan kurang maka, anak didik dapat menambahkan pendidikan agama tersebut dari pendidikan dari luar sekolah formal atau pindah ke sekolah madrasah.

Peranan Pendidikan Islam dan Pendidikan Moral membentuk personaliti pelajar yang mencakupi aspek emosi, intelek, rohani dan jasmani seiring dengan falsafah pendidikan negara, maka pendidikan agama islam harus berperan sebagai berikut:

a. Membentuk watak serta peradaban bangsa dalam rangka membangun manusia seutuhnya dan masyarakat Indonesia seluruhnya, maka pendidikan agama berperan sebagai berikut:

\footnotetext{
${ }^{14}$ Departemen Pendidikan dan Kebudayaan, Direktorat Jenderal Pendidikan Dasar dan Menengah, Bagian Proyek Peningkatan Wawasan Kependidikan Guru Agama. Bahan Dasar Peningkatan Keagamaan (Islam) Guru Bukan Pendidikan Agama dan SLTA. Jakarta: Depdikbud, 1998. Hlm. 92.

${ }^{15}$ Prayitno. Dasar Teori dan Praksis Pendidikan. Jakarta: Grasindo 2009. Hlm. 259
} 
1) dalam aspek individu, untuk membentuk manusia yang beriman dan bertakwa.

2) dalam aspek kehidupan bermasyarakat dan bernegara, untuk membimbing warga negara Indonesia menjadi warga negara yang baik sekaligus umat yang taat menjalankan ibadahnya.

b. Menjadi manusia yang beriman dan bertakwa, maksudnya adalah manusia yang selalu tunduk dan taat terhadap apa-apa yang diperintahkan oleh Allah Swt, dan menjauhi segala larangannya.

c. Berakhlak mulia, sehat, berilmu, cakap, kreatif, dan mandiri. Maksudnya adalah sikap utuh dan seimbang antara kekuatan intelektual dan kekuatan spiritual yang secara langsung termanifestasikan dalam bentuk akhlak mulia.

d. Menjadi warga negara yang demokratis serta bertanggung jawab, maksudnya adalah perwujudan dari iman dan takwa itu dimanifestasikan dalam bentuk kecintaan terhadap tanah air.

Selain itu, apabila dilihat dari kurikulum dan lembaga pendidikan, maka peran Pendidikan Islam dalam sistem pendidikan nasional adalah:

a. Sebagai mata pelajaran. Pendidikan Agama Islam sebagai mata pelajaran wajib di seluruh jenjang pendidikan sekolah di Indonesia berperan: ${ }^{16}$

1) Mempercepat proses pencapaian tujuan pendidikan Nasional

Pendidikan Nasional bertujuan untuk berkembangnya potensi peserta didik agar menjadi manusia yang beriman kepada Tuhan yang Maha Esa, berakhlak mulia, sehat, berilmu,cakap, kreatif, mandiri, dan menjadi warga Negara yang demokratis serta bertanggung

${ }^{16}$ Ramayulis. Ilmu Pendidikan Islam. Jakarta: Kalam Mulia, 2002. HIm. 75-80 jawab. Secara sederhana dapat dirinci materi pokok yang terdapat dalam tujuan Nasional:

a) Berkembangnya potensi anak didik

b) Beriman dan bertakwa kepada Tuhan yang maha Esa

c) Berakhlak mulia, sehat, berilmu, cakap, kreatif dan mandiri.

d) Menjadi warga negara yang demokratis.

e) Bertanggung jawab.

2) Memberikan nilai terhadap mata pelajaran umum. Nilai-nilai yang terdapat dalam pelajaran Islam inilah yang diinternalisasikan dalam proses pembelajaran kepada peserta didik.

b. Sebagai lembaga pendidikan. Madrasah sebagai sub sistem pendidikan nasional tidak hanya dituntut untuk dapat menyelenggarakan pendidikan dasar dan menengah yang bercirikan keagamaan, tetapi lebih jauh madrasah dituntut pula memainkan peran lebih besar yaitu sebagai basis dan benteng tangguh yang akan menjaga dan memperkokoh etika dan moral bangsa. Maka dalam hal ini madrasah memainkan perannya sebagai berikut:

1) Media sosialisasi nilai-nilai ajaran agama islam

2) Memelihara tradisi keagamaan

3) Membentuk akhlak dan karakter

4) Benteng moralitas bangsa

5) Lembaga pendidikan alternatif

Peran tersebut didasarakan pada ketentuan yang terdapat dalam UndangUndang Sistem Pendidikan Nasional, yang diatur sebagai berikut:

1) memperkuat kedudukan pendidikan agama islam dalam SISDIKNAS

2) memperluas jangkauan dan sasaran pendidikan agama 
3) memberikan jaminan secara yuridis formal bahwa peserta didik akan mendapatkan pengajaran agama sesuai dengan agama yang diyakininya dan diajarkan oleh guru yang seagama.

4) memberi peluang dan kesempatan untuk berkembangnya pendidikan islam secara terintegrasi dalam sistem pendidikan nasional

Ketentuan yang terdapat dalam sistem pendidikan nasional sangat mendukung untuk tumbuh dan berkembangnya pendidikan agama Islam baik dalam materi kurikulum pendidikan atau pendidikan keagamaan sebagai satuan pendididikan. Sejalan dengan tujuan nasional yang telah ditentukan, maka tugas dan fungsi pendidikan agama adalah membangun pondasi bangsa Indonesia, yaitu pondasi mental-spiritual yang berakartunggang pada faktor keimanan dan ketakwaan yang berfungsi sebagai pengendali, pattern of reference spiritual dan sebagai pengokoh jiwa bangsa melalui pribadi-pribadi yang tahan banting dalam segala cuaca perjuangan. ${ }^{17}$

Menurut Jusuf A. Faisal bahwa fungsi pendidikan yang bertitik tolak dari Iman-Islam-Ihsan atau Akidah, Ibadah, Akhlak, untuk menuju kemuliaan manusia dan budaya yang diridhoi Allah Swt, maka setidak-tidaknya fungsi pendidikan islam sebagai berikut: ${ }^{18}$

a. Individualisai nilai dan ajaran Islam demi terbentuknya derajat manusia muttaqin dalam bersikap, berpikir, dan berperilaku.

b. Sosialisasi nilai-nilai dan ajaran Islam demi terbentuknya umat Islam.

c. Rekayasa kultur Islam demi terbentuk dan berkembangnya peradaban Islam

\footnotetext{
${ }^{17}$ Muzayyin Arifin. Kapita Selekta Pendidikan Islam. Jakarta, PT Bumi Aksara, 2007. Hlm. 141.

${ }^{18}$ Jusaf Amir Faisal. Reorinatasi Pendidikan Islam. Jakarta Gema insani, 1995. Hlm. 95-96.
}

d. Menemukan, mengembangkan serta memalihara ilmu, teknologi, dan keterampilan demi terbentuknya para manajer dan manusia profesional.

e. Pengembangan intelektual muslim yang mampu mencari mengembangkan serta memelihara ilmu dan teknologi.

f. Pengembangan pendidikan yang berkelanjutan dalam bidang ekonomi, fisika, kimia, arsitektur, seni musik, seni budaya, politik, olahraga, kesehatran, dan sebagaiuanya.

g. Pengembangan kualitas muslim dan warga negara sebagai angggota dan pembina masyarakat yang berkulitas kompetitif.

Fungsi pendidikan Islam mencakup saluruh aspek kehidupan, dari mulai aspek psikologis, sosial, budaya, dan ekonomi. Oleh karena itu, pendidikan Islam seharusnya terintegrasi dengan seluruh ilmu dan pengetahuan. Sebagaimana ketika Islam menguasai peradaban pada masa Abbasiyah, saat itu ilmu pengetahuan Islam terintegrasi dengan semua disiplin ilmu pengetahuan. Sehingga fungsi pendidikan agama Islam, dijelaskan sebagai berikut:

1. Pengembangan fungsi pendidikan agama Islam dalam bentuk dan ketakwaan kepada Allah Swt dan akhlak mulia..

2. Kegiatan pendidikan dan pengajaran.Pendidikan agama harus memberikan nilai-nilai mulia atau universal yang harus dimiliki dan diaplikasikan dalam perilakunya.

3. Mencerdaskan Kehidupan Bangsa.Kehidupan bangsa yang cerdas diwujudkan melalui terwujudnya manusia Indonesia yang memiliki daya saing dalam kompetisi global dengan memiliki iman dan ketakwaan dengan ilmu pengetahuan dan teknologi yang kuat.

4. Fungsi integrasi studi keilmuan. Pendidkan Islam dengan sumber ajaran 
pokoknya al-qur'an dan hadis dapat menjadikan terintegrasinya seluruh studi keilmuan dengan ilmu agama, dari mulai psikologis sampai dengan kemajuan teknologi.

\section{Aplikasi Pendidikan Islam di Sekolah}

Dari fakta-fakta dilapangan terdapat beberapa hal yang harus diperhatikan oleh pemerintah terkait dengan pelaksanaan regulasi pendidikan antara laian:

1. Laporan Pelaksanaan Pendidikan Agama pada Sekolah Swasta. Pemerintah harus melakukan evaluasi terhadap administrasi pendidikan agama dari sekolah agama swasta yang memiliki siswa dengan agama yang berbeda dengan agama yang dianut oleh mayoritas siswa yang ada sekolah tersebut. Pengawas, dapat menilai laporan pelaksanaan pendidikan agama dengan keberadaan guru agama islam di sekolah tersebut, sehingga sekolah tersebut harus melaksanakan ketentuan Undang-Undang Sistem Pendidikan Nasional Nomor 20 tahun 2003 pasal 12 ayat (1) huruf a yang menyatakan bahwa "Setiap peserta didik pada setiap satuan pendidikan berhak mendapatkan pendidikan agama sesuai dengan agama yang dianutnya dan diajarkan oleh pendidikan yang seagama".

2. Banyak Tawuran. Pelajaran pendidikan agama sudah diajarkan di sekolah sejak mulai SD. Akan tetapi masih banyak siswa yang tawuran di berbagai tempat. Padahal dalam pasal 37 ayat (1) huruf a Undang-Undang Sistem Pendidikan Nasional Nomor 20 tahun 2003 dinyatakan bahwa Kurikulum pendidikan dasar dan menengah wajib memuat pendidikan agama. Ditambahkan juga dengan penjelasannya bahwa Pendidikan agama dimaksudkan untuk membentuk peserta didik menjadi manusia yang beriman dan bertakwa kepada Tuhan Yang Maha Esa serta berakhlak mulia.

3. Pembelajaran Baca Tulis Al-qur'an dan Bahasa Arab. Al-qura'n sebagai pedoman utama umat Islam atau sebagai sumber hukum. Saat ini terdapat beberapa siswa yang belum bisa atau belum lancar membaca dan menulis Al-qur'an Seluruh siswa yang beragama Islam harus bisa membaca Al-qur'an. Selain itu di Sekolah SDN, SMPN, dan SMAN tidak terdapat pelajaran bahasa Arab. Pelajaran bahasa Arab hanya ada di Sekolah Islam Terpadu dan Madrasah. Padahal pendidikan agama dimulai dari SD dan dipertegas lagi pada arah kebijakan pendidikan Islam mengacu pada arah kebijakan Kementerian Agama Bidang Pendidikan 2015-2019 salah satunya adalah melaksanakan strategi dalam meningkatkan mutu dan pemahaman siswa terhadap ajaran Islam berupa pemberian kesempatan bagi siswa untuk mengikuti pelatihan Tuntas Baca Tulis Qur`an (TBTQ). ${ }^{19}$

4. Perbaikan Administrasi Pendidikan Agama Islam. Pelaksanaan pendidikan akan berjalan dengan optimal apabila seluruh pelaksanaan teknis dan administrasi berjalan dengan tertib. Masalah yang sering muncul dalam hal ini adalah pembayaran tunjangan kepada para guru dan dosen. Selain itu, yang utama juga adalah pemberian dana bantuan operasional sekolah, pemberian bantuan dan sosialisasi Kartu Indonesia Pintar (KIP), dan pemberian bantuan operasional pendidikan (BOP). Kesemua hal tersebut harus berjalan tepat waktu, efektif, dan efisien. Untuk mewujudkan

\footnotetext{
${ }^{19}$ Arah Kebijakan Pendidikan. Islam http: //pendis.kemenag.go.id/index.php?a=artikel \&id2 $=$ strategi pendis, di unduh pada tanggal 01 Januari 2018.
} 
hal ini adalah dengan meningkatkan pengawasan dalam pelaksanaan pencairannya berupa tata cara dan ketentuannya.

5. Integrasi Pendidikan Umum dan Pendidikan Agama. Pelaksanaan pendidikan di Indonesia mengalami dua pembagian yaitu lembaga pendidikan umum dan lembaga pendidikan agama. Keduanya tampak jelas perbedaan kualitasnya. Lembaga pendidikan umum cenderung sangat maju, sedangkan lembaga pendidikan agama kemajuannya tidak secepat sekolah umum. Selain itu terdapat beberapa "stempel negatif" dalam sekolah agama salah satunya radikalisme. Pertama, tuduhan radikalisme ini, selain diidentikkan pada lembaga pendidikan agama juga terhadap organisasi sekolah yang beraliran agama Islam. Hal tersebut juga menjadi perhatian dari kebijakan Pendidikan Islam pada kebijakan Kementerian Agama Bidang Pendidikan 2015-2019. ${ }^{20}$

Kebijakan tersebut dilaksanakan melalui strategi dalam meningkatkan kualitas pembelajaran Pendidikan Islam yang moderat pada pendidikan diniyah dan pondok pesantren berupa:

a. Penyelenggaraan Tahkiq atas Kitab Karya Ulama Nusantara.

b. Sosialisasi pemahaman keagamaan yang toleran (tasamuh), seimbang (tawazun), moderat (tawasuth), dan cinta tanah air.

c. Penyelenggaraan deradikalisasi keagamaan pada lembaga pendidikan keagamaan.

Agama Islam yang memiliki pedoman atau sumber hukum berupa Al-

${ }^{20}$ Arah Kebijakan Pendidikan. Islam http: //pendis.kemenag.go.id/ index.php?a= artikel \&id2 =strategi pendis, di unduh pada tanggal 01 Januari 2018. qur'an dan hadis. Kedua pedoman tersebut tidak ada yang melegalkan radikalisme dalam suatu negara yang damai berupa menghormati dan menghargai antar sesama agama. Sehingga tidak tepat julukan radikalisme negatif yang ditujukan kepada penganut agama Islam. Menurut Dede Mariana, bahwa secara teoritis, radikalisme tidak identik dengan kekerasan, termasuk penyandingannya dengan kelompok agama tertentu. Fenomena radikalisme agama bukanlah fenomena yang lahir saat ini saja. Radikalisme agama telah lahir sejak abad 16-19 M, di mana perebutan hegemoni agama antara Islam versus Kristen sangat kentara di sana. Fenomena radikalisme agama juga bukan hanya milik Islam, maupun Kristen, tetapi juga dalam Hindu dan Yahudi, demikian Karen Amstrong, dalam The Battle for God, 2000. ${ }^{21}$

Para pengajar pada lembaga pendidikan keagamaan dan para siswa dalam kegiatan organisasi sekolah hendaknya tetap istiqomah dalam mengajarkan pendidikan agama, tanpa ada ketakutan untuk dituduh radikalisme. Pendidikan agama tersebut harus berpedoman pada Al-qur'an dan hadis. Begitu juga dalam menghadapi organisasi keagamaan yang mengatasnamakan agama dalam menjalankan kegiatannya, maka hendaknya para mengajar memastikan pedoman apa yang dibawanya dan diwajibkan untuk saling menghormati dan menghargai dengan pemeluk agama lain dengan mengutamakan persatuan, khususnya terhadap sesama organisasi agama Islam dengan menghindari perpecahan, begitu juga terhadap pemeluk agama lain pada umumnya dengan menerapkan nilai-nilai Islam yang bersifat universal.

\footnotetext{
${ }^{21}$ Dede Mariana. Radikalisme Agama \& Politik. https://tandamatabdg.wordpress.com/ 2017/05/12/radikalisme-agama-politik/diunduh pada tanggal 3 Janauari 2018.
} 
Di Indonesia, awal mula terjadi pemisahan lembaga pendidikan umum dan lembaga pendidikan agama adalah pada saat terjadi penjajahan. Karena saat itu, penjajah tidak memperhatikan pendidikan agama Islam yang dianut oleh mayoritas rakyat Indonesia karena berbeda agama dan ideologinya dengan mayotitas rakyat Indonesia. Para ulama dan santri memandang sistem pendidikan yang diselenggarakan penjajah sangat menyimpang dari ajaran Islam. Sehingga banyak para ulama yang mendirikan lembaga pendidikan sendiri tanpa bantuan dan campur tangan dari pihak penjajah. Sedangkan pihak penjajah menyelenggarakan pendidikan di wilayah jajahan bertujuan untuk mempertahankan hegemoninya di tanah jajahan.

\section{E. Penutup}

Indonesia sebagai negara besar yang mayoritas penduduknya beragama Islam, seharusnya pendidikan Islam berkembang dan maju. Akan tetapi sampai dengan saat ini, pendidikan Islam masih tertinggal dan kalah bersaing dengan sekolah umum. Saat ini pemerintah sudah mengeluarkan regulasi terkait pendidikan Islam seperti Undang-undang No. 20 tentang Sistem Pendidikan Nasional, Undang-Undang Nomor 12 tahun 2012 tentang Pendidikan Tinggi, dan Peraturan Pemerintah Nomor 55 tahun 2007 tentang Pendidikan Agama dan Pendidikan Keagamaan. Dengan ketentuan tersebut keberadan pendidikan Islam diakui dalam tata hukum Indonesia melalui materi kurikulum pendidikan agama Islam yang diwajibkan dalam setiap jenjang pendidikan. Sedangkan terhadap lembaga pendidikan agama Islam materi diberikan dengan lebih banyak seperti: aqidah, tafsir, hadis, usul fikih, fikih, akhlak, tasawuf, dan tarikh Islam. Selain itu, satuan pendidikan dapat menambah muatan pendidikan agama sesuai kebutuhan. Berdasarkan realitas, maka terdapat beberapa hal yang harus diperhatikan oleh pemerintah untuk dilakukan perbaikan demi mewujukan pendidikan yang sesuai dengan tujuan negara Indoensia yaitu (1) laporan pelaksanaan pendidikan agama pada sekolah swasta, (2) pembelajaran baca tulis al-qur'an dan bahasa arab, (3) perbaikan administrasi pendidikan agama Islam, (4) banyak Tawuran, dan (5) Integrasi Pendidikan Umum dan Pendidikan Agama

\section{DAFTAR PUSTAKA}

Azyumardi Azra. Pendidikan Islam Tradisi dan Modernisasi Menuju Millennium Baru. Jakarta: logos wacana ilmu, 1999.

Abuddin Nata. Pendidikan dalam Perspektif Al-qur'an Edisi Pertama. Jakarta: Kharisma Putra Utama, 2016.

Asep Herdi dan Asep Supriatna. Memahami Ilmu Hadis. Bandung: Tafakur, 2014.

Aqib Suminto dalam Politik Islam, sebagaiman dikutip oleh Imam Fuadi. Sejarah Pendidikan Islam. Tulungagung: IAIN Tulungagung Press, 2014

Atas Hendartini Habsjah dan Mooriati Sudiharto. Perjalanan Panjang Anakn Bumi. Jakarta: Yayasan Obor Indonesia, 2008

Abdul Rachman Saleh. Pendidikan Agama dan Keagamaan, Visi, Misi, dan Aksi. Jakarta: PT. Maries, 1999.

Departemen Pendidikan dan Kebudayaan, Direktorat Jenderal Pendidikan Dasar dan Menengah, Bagian Proyek Peningkatan Wawasan Kependidikan Guru Agama. Bahan Dasar Peningkatan Keagamaan (Islam) 
Guru Bukan Pendidikan Agama dan SLTA. Jakarta: Depdikbud, 1998

Depertemen Agama Direktorat Jendral. Kelembagaan Agama Islam. Pendidikan Islam dan Pendidikan Nasional ( paradigma baru). Jakarta: 2005

Jusaf Amir Faisal. Reorinatasi Pendidikan Islam. Jakarta Gema insani, 1995

Moh Roqib. Ilmu Pendidikan Islam. Yogyakarta: LkiS Pelangi Aksara, 2009

Muzayyin Arifin. Kapita Selekta Pendidikan Islam. Jakarta, PT Bumi Aksara, 2007

Hasan Langgulung. Beberapa Pemikiran Tentang Pendidikan Islam. Bandung: Al-Ma'rif, 1980.

Prayitno. Dasar Teori dan Praksis Pendidikan. Jakarta: Grasindo 2009.

Ramayulis. Ilmu Pendidikan Islam. Jakarta: Klam Mulia, 1994
Ramayulis. Ilmu Pendidikan Islam. Jakarta: Kalam Mulia, 2002

Tim Pengembang Ilmu Pendidikan FIP UPI. Ilmu dan aplikasi pendidikan. Jakarta: Imtima, 2007

Arah Kebijakan Pendidikan. Islam http://pendis.kemenag.go.id/ index.php?a $=$ artikel \&id2 =strategi pendis, di unduh pada tanggal 01 Januari 2018.

Arah Kebijakan Pendidikan. Islam http://pendis.kemenag.go.id/ index.php?a $=$ artikel \&id2 $=$ strategi pendis, di unduh pada tanggal 01 Januari 2018.

Dede Mariana. Radikalisme Agama\&Politik.

https://tandamatabdg.wordpress.com/ 2017/05/12/radikalisme-agamapolitik/ diunduh pada tanggal 3 Jnauari 2018. 